\title{
Preclinical evaluation of a novel engineered recombinant human anti-CD44v6 antibody for potential use in radio-immunotherapy
}

\author{
ANJA C. MORTENSEN ${ }^{1}$, DIANA SPIEGELBERG ${ }^{1}$, ANNA-KARIN HAYLOCK ${ }^{2}$, \\ HANS LUNDQVIST $^{1}$ and MARIKA NESTOR ${ }^{1}$
}

\author{
${ }^{1}$ Department of Immunology, Genetics and Pathology, Uppsala University; ${ }^{2}$ Unit of Otolaryngology \\ and Head and Neck Surgery, Department of Surgical Sciences, Uppsala University, SE-75185 Uppsala, Sweden
}

Received October 16, 2017; Accepted January 29, 2018

DOI: $10.3892 /$ ijo.2018.4364

\begin{abstract}
CD44v6 is overexpressed in a variety of cancers, rendering it a promising target for radio-immunotherapy (RIT). In this study, we have characterized a novel engineered recombinant monoclonal anti-CD44v6 antibody, AbN44v6, and assessed its potential for use in RIT using either ${ }^{177} \mathrm{Lu}$ or ${ }^{131} \mathrm{I}$ as therapeutic radionuclides. In vitro affinity and specificity assays characterized the binding of the antibody labeled with ${ }^{177} \mathrm{Lu},{ }^{125} \mathrm{I}$ or ${ }^{131} \mathrm{I}$. The therapeutic effects of ${ }^{177} \mathrm{Lu}-\mathrm{AbN} 44 \mathrm{v} 6$ and ${ }^{131} \mathrm{I}-\mathrm{AbN} 44 \mathrm{v} 6$ were investigated using two in vitro 3D tumor models with different CD44v6 expression. Finally, the normal tissue biodistribution and dosimetry for ${ }^{177} \mathrm{Lu}-\mathrm{AbN} 44 \mathrm{v} 6$ and ${ }^{125} \mathrm{I}-\mathrm{AbN} 44 \mathrm{v} 6 /{ }^{131} \mathrm{I}-\mathrm{AbN} 44 \mathrm{v} 6$ were assessed in vivo using a mouse model. All AbN44v6 radioconjugates demonstrated CD44v6-specific binding in vitro. In the in vitro 3D tumor models, dose-dependent therapeutic effects were observed with both ${ }^{177} \mathrm{Lu}-\mathrm{AbN} 44 \mathrm{v} 6$ and ${ }^{131} \mathrm{I}-\mathrm{AbN} 44 \mathrm{v} 6$, with a greater significant therapeutic effect observed on the cells with a higher CD44v6 expression. Biodistribution experiments demonstrated a greater uptake of ${ }^{177} \mathrm{Lu}-\mathrm{AbN} 44 \mathrm{v} 6$ in the liver, spleen and bone, compared to ${ }^{125} \mathrm{I}-\mathrm{AbN} 44 \mathrm{v} 6$, whereas ${ }^{125} \mathrm{I}-\mathrm{AbN} 44 \mathrm{v} 6$ demonstrated a longer circulation time. In dosimetric calculations, the critical organs for ${ }^{177} \mathrm{Lu}-\mathrm{AbN} 44 \mathrm{v} 6$ were the liver and spleen, whereas the kidneys and red marrow were considered the critical organs for ${ }^{131} \mathrm{I}-\mathrm{AbN} 44 \mathrm{v} 6$. The effective dose was in the order of $0.1 \mathrm{mSv} / \mathrm{MBq}$ for both labels. In conclusion, AbN44v6 bound specifically and with high affinity to CD44v6. Furthermore, in vitro RIT demonstrated growth inhibition in a CD44v6specific activity-dependent manner for both radioconjugates, demonstrating that both ${ }^{177} \mathrm{Lu}-\mathrm{AbN} 44 \mathrm{v} 6$ and ${ }^{131} \mathrm{I}-\mathrm{AbN} 44 \mathrm{v} 6$ may be promising RIT candidates. Furthermore, biodistribution and dosimetric analysis supported the applicability of both
\end{abstract}

Correspondence to: $\operatorname{Dr}$ Anja C. Mortensen, Department of Immunology, Genetics and Pathology, Uppsala University, Dag Hammarskjölds Väg 20, SE-75185 Uppsala, Sweden

E-mail: anja.mortensen@igp.uu.se

Key words: radio-immunotherapy, 3D tumor models, dosimetry, biodistribution, ${ }^{177} \mathrm{Lu},{ }^{131} \mathrm{I}$ conjugates for RIT. The CD44v6-specific therapeutic effects observed with radiolabeled AbN44v6 in the 3D tumor models in vitro, combined with the beneficial dosimetry in vivo, render AbN44v6 a potential candidate for RIT.

\section{Introduction}

Despite continuous advances in its prevention, diagnosis and treatment, cancer remains a leading cause of mortality worldwide. In recent years, the concepts of precision medicine and targeted therapies have been on the rise and continue to gain momentum (1). Targeted radiotherapy (TRT) has been in use for over half a century, and may be a promising method with which to improve precision medicine in several malignancies. By targeting a structure that is abundant in tumor cells, but is rare in healthy tissues, a targeting molecule can mediate the delivery of radioactivity specifically to tumor cells in the body. By coupling a diagnostic radionuclide to the agent, one can non-invasively characterize tumors using positron emission tomography (PET) or single photon emission computed tomography (SPECT), for use in e.g. patient stratification, treatment response monitoring and to detect occult tumors or metastases (2). Moreover, by coupling therapeutic nuclides to a targeting agent, such as monoclonal antibodies for radio-immunotherapy (RIT) or peptides for peptide receptor radiotherapy $(2,3)$, the therapeutic radiation dose to the tumor can be maximized, while exposure to normal tissue is minimized (4). Two of the main challenges of TRT are identifying suitable targets, which should ideally be confined to cancer cells or the surrounding stroma, and developing a tracer that is highly specific to its target. The optimal combination allows for the use of a 'magic bullet', which delivers radiation mainly to cancer cells without damaging healthy, surrounding tissue in the process.

Plausible targets are variants of the family of the cluster of differentiation (CD)44, the main cell surface receptor for hyaluronic acid. The standard form of CD44 is found throughout most tissues, whereas the different CD44 exon splicing variants (CD44v3-10), which are the result of alternative splicing and post-translational modifications, are much more tissuespecific (5). CD44 variant 6 (CD44v6) is of particular interest as a target for RIT. Several studies have demonstrated the overexpression of CD44v6 in several cancers, including but not limited to head and neck, breast, ovarian, prostate, colon and colorectal 
cancer (6-11), whereas CD44v6 expression in normal tissue is restricted to the squamous and transitional epithelium $(12,13)$. Additionally, the overexpression of CD44v6 is associated with a poor prognosis and a more aggressive, chemoresistant disease in several cancer types (7-9,14-18). In metastatic tissue, a retained or increased CD44v6 expression compared to primary tumors has been demonstrated in certain types of cancer, such as squamous cell carcinomas, prostate cancer and ovarian cancer $(7,9,19,20)$, whereas studies on colorectal cancers have reported heterogeneous results (21). Of note, CD44v6 has also been associated with 'cancer stem cell-like properties' in certain types of cancer $(6,22)$. Consequently, the low level of expression in healthy tissue, coupled with the overexpression on a variety of different cancer types, renders CD44v6 a promising target for TRT (23). The possibility of utilizing CD44v6 for personalized medicine has recently been demonstrated by small animal PET, where a novel, recombinant bivalent mini-antibody was used to visualize xenografts in a mouse model $(24,25)$. Furthermore, CD44v6 has previously been evaluated as a target for RIT with promising results in patients with head and neck squamous cell carcinoma using a humanized monoclonal antibody (BIWA 4) with ${ }^{186} \mathrm{Re}$ as a therapeutic nuclide (26).

Two of the most commonly used radionuclides in TRT currently are ${ }^{177} \mathrm{Lu}$ and ${ }^{131} \mathrm{I}(27-31) .{ }^{177} \mathrm{Lu}$ has been gaining importance in clinical practice and has been used with great success in peptide receptor radiotherapy, particularly when labeled to somatostatin analogues for the treatment of neuroendocrine cancer (29). ${ }^{131} \mathrm{I}$ is unique in its history within the field of oncology, as it has been in use for 70 years for the treatment of hyperthyroidism and thyroid cancer (29,32-34). The two beta emitters share similar characteristics, particularly with regard to their half-lives (6.7 and 8.0 days, respectively), mean beta energy emission (133 and $182 \mathrm{keV}$, respectively) as well as the mean range in vivo ( 0.25 and $0.4 \mathrm{~mm}$, respectively). Both emitters also emit gamma radiation, where the dominant energies are $208 \mathrm{keV}(11 \%)$ and $113 \mathrm{keV}(5 \%)$ for ${ }^{177} \mathrm{Lu}$ and $364 \mathrm{keV}(82 \%)$ and $637 \mathrm{keV}(7 \%)$ for ${ }^{131} \mathrm{I}$. The gamma emissions of both nuclides offer the possibility of using SPECT to monitor the response to treatment, although the higher gamma energies of ${ }^{131} \mathrm{I}$ are less favorable. Furthermore, the slightly shorter range of ${ }^{177} \mathrm{Lu}$ makes it more suitable for micrometastases and minimizes the risk of toxicity to adjacent tissue (29).

We have recently developed a fully human recombinant monoclonal antibody targeting CD44v6, AbN44v6. It was derived from a Fab (AbD15179), previously developed by our group for use within the field of molecular imaging, shown to bind selectively and with high affinity to CD44v6 (24). The full-length variant AbN44v6 was developed for the purpose of targeted therapy and has not previously been evaluated or characterized.

The aim of this study was to characterize AbN44v6 and examine the possibility of utilizing the antibody for RIT, using ${ }^{177} \mathrm{Lu}$ or ${ }^{131} \mathrm{I}$ as therapeutic nuclides. The affinity and specificity of the conjugates were first characterized in vitro. RIT in an in vitro $3 \mathrm{D}$ tumor model was then assessed, comparing the therapeutic effects of ${ }^{177} \mathrm{Lu}$ - and ${ }^{131} \mathrm{I}$-labeled AbN44v6 in two models with different CD44v6 expression. Finally, a dual nuclide biodistribution and dosimetric analysis of ${ }^{177} \mathrm{Lu}-\mathrm{AbN} 44 \mathrm{v} 6$ and ${ }^{125} \mathrm{I}-\mathrm{AbN} 44 \mathrm{v} 6$ (as a model for ${ }^{131} \mathrm{I}-\mathrm{AbN} 44 \mathrm{v} 6$ ) was performed in normal tissues in vivo using a mouse model.

\section{Materials and methods}

Cell lines. The human colorectal carcinoma cell line, HCT116, previously demonstrated to express moderate amounts of CD44v6 (16) was purchased from ATCC (Manassas, VA, USA) and cultured in McCoy's modified Eagle's medium (Biochrom Kg, Berlin, Germany) with $10 \%$ fetal bovine serum (Sigma-Aldrich, St. Louis, MO, USA), 1\% L-glutamine and 1\% antibiotics (100 IU penicillin and $100 \mu \mathrm{g} / \mathrm{ml}$ streptomycin (all from Biochrom $\mathrm{Kg}$ ). The human squamous cell carcinoma cell line, UM-SCC-74B, previously shown to express a low amount of CD44v6 $(24,25)$ was kindly provided by Professor T.E. Carey (University of Michigan, Ann Arbor, MI, USA) and cultured in Dulbecco's modified Eagle's medium (DMEM) (Biochrom Kg) with the same supplements, and $1 \%$ non-essential amino acids (Thermo Fisher Scientific, Uppsala, Sweden). The cells were incubated at $37^{\circ} \mathrm{C}$ in a $5 \% \mathrm{CO}_{2}$ atmosphere and cultured for no longer than three months.

Antibodies. AbD15179 was converted to the full-length human IgG1 isotype in collaboration with Bio-Rad AbD Serotec (Puchheim, Germany) as described below. Variable domain VH and VL gene fragments were subcloned into the pMORPH2_h_Ig vector series for human IgG1 expression $(35,36)$ using $M f e \mathrm{I} / B l p \mathrm{I}$ for insertion into the HC vector backbone and EcoRV/BsiWI for insertion into the $\mathrm{LC}$ vector backbone. These vectors carry the human Ig constant region and the human kappa constant region, respectively. Antibody expression was performed transiently using the HKB11 cells (ATCC) (37) in a humidified atmosphere at $37^{\circ} \mathrm{C}$ and $5 \% \mathrm{CO}_{2}$. The day prior to transfection, $100 \mathrm{ml}$ HKB11 cells were seeded at $0.5 \times 10^{6}$ viable cells $/ \mathrm{ml}$ in a shake flask containing MAC1.0 medium supplemented with $1 \%$ FCS. Transfection was carried out by the addition of $100 \mu \mathrm{g}$ of each expression construct followed by $400 \mu \mathrm{l}$ Q-PEI transfection reagent (Polyplus, Illkirch, France). At $3 \mathrm{~h}$ post-transfection $100 \mathrm{ml}$ ExCell-VPRO medium (Sigma-Aldrich, Stockholm, Sweden) containing 1\% FCS and 1X GlutaMAX (Thermo Fisher Scientific) were added to the cells. Cell culture supernatants were harvested at day 6 post-transfection and subjected to protein A affinity chromatography. The purified antibody AbD15179_hIgG1, here referred to as AbN44v6, was re-buffered to either PBS, pH $7(1.2 \mathrm{mg} / \mathrm{ml})$, or $0.07 \mathrm{M}$ sodium borate, $\mathrm{pH} 9.2$ ( $3 \mathrm{mg} / \mathrm{ml})$. The commercially available anti-CD20 full antibody, rituximab (cat. no. 494237), was purchased commercially from Apoteket AB (Luleå, Sweden).

Radionuclides and labeling. The two beta emitters ${ }^{177} \mathrm{Lu}$ and ${ }^{131}$ I were selected for the study as they are highly relevant as therapeutic radionuclides in nuclear medicine, and share similar characteristics with regard to half-life, mean beta energy emission and mean range in vivo. The ${ }^{177} \mathrm{Lu}$ and ${ }^{131} \mathrm{I}$ isotopes were purchased from PerkinElmer (Waltham, MA, USA) as ${ }^{177} \mathrm{LuCl}_{3}$, $\mathrm{pH} 1$, and $0.1 \mathrm{M}{ }^{131} \mathrm{I}-\mathrm{NaOH}, \mathrm{pH} 12-14$, respectively. For ${ }^{177} \mathrm{Lu}$ labeling, AbN44v6 and rituximab were chelated in $0.07 \mathrm{M}$ sodium borate, $\mathrm{pH}$ 9.2, with CHX-A"DTPA at a molar ratio of 1:5 during an incubation period of $4 \mathrm{~h}$ at $37^{\circ} \mathrm{C}$. The excess CHX-A"DTPA was separated from the antibodies using a NAP5 size exclusion chromatography column (GE Healthcare, Uppsala, Sweden) equilibrated with filtered 0.2 M ammonium acetate, $\mathrm{pH}$ 5.5, stored over Chelex 100. Subsequently, 
1-30 $\mathrm{MBq}$ of ${ }^{177} \mathrm{LuCl}_{3}$ was added to $10-375 \mu \mathrm{g}$ of AbN44v6 and 4-40 MBq of ${ }^{177} \mathrm{LuCl}_{3}$ was added to $100-200 \mu \mathrm{g}$ of rituximab, and incubated for $1 \mathrm{~h}$ at room temperature. For in vitro experiments, the free ${ }^{177} \mathrm{Lu}$ was purified from labeled antibody using a NAP5 size exclusion chromatography column equilibrated with serum-free medium. For in vivo experiments, the ${ }^{177} \mathrm{Lu}$-labeled AbN44v6 was purified using Nanosep 3K (Pall Norden AB, Lund, Sweden); the sample was added to four different filters and centrifuged for $35 \mathrm{~min}$ at 14,000 $\mathrm{x}$ g before washing twice with $200 \mu \mathrm{l}$ of MQ water for $30 \mathrm{~min}$ at $14,000 \mathrm{x} \mathrm{g}$.

The direct iodination of both AbN44v6 and rituximab with ${ }^{131} \mathrm{I}$ or ${ }^{125} \mathrm{I}$ was performed by the addition of $40 \mu \mathrm{l}$ ( $4 \mathrm{mg} / \mathrm{ml}$ ) of Chloramine-T (CAT) to typically 20-375 $\mu \mathrm{l}$ of antibody $(1.2 \mathrm{mg} / \mathrm{ml})$ and 2-20 MBq of radioiodine for $60 \mathrm{sec}$ on ice prior to terminating the reaction with $80 \mu \mathrm{l}(4 \mathrm{mg} / \mathrm{ml})$ $\mathrm{Na}_{2} \mathrm{SO} 5$ (NBS).

To determine the labeling yield, purity and stability of the labeled antibody fragments, ITLC was performed on ${ }^{131} \mathrm{I}$, ${ }^{125} \mathrm{I}-$ and ${ }^{177} \mathrm{Lu}$-labeled conjugates. Approximately $0.5 \mu \mathrm{l}$ of the conjugate was placed on a chromatography strip (Biodex, Shirley, NY, USA) and placed into a 'running buffer' (70\% acetone for ${ }^{131} \mathrm{I}$ and ${ }^{125} \mathrm{I}$ or $0.2 \mathrm{M}$ citric acid for ${ }^{177} \mathrm{Lu}$ ), followed by measurements on a Cyclone Storage Phosphor System (PerkinElmer). The data were analyzed using the OptiQuant image analysis software (PerkinElmer). The purity of the samples taken immediately, as well as stored at $4^{\circ} \mathrm{C}$ for $48 \mathrm{~h}$, was analyzed. An ethylenediaminetetraacetic acid (EDTA) challenge assessed the stability of the ${ }^{177}$ Lu-labeled antibody using a 500-fold molar excess of EDTA and determined the stability by ITLC following incubation at $37^{\circ} \mathrm{C}$ for $48 \mathrm{~h}$. The purification of both antibodies resulted in $100 \%$ purity for radio-iodination and $>95 \%$ for ${ }^{177}$ Lu-labeling.

In vitro specificity. In order to assess CD44v6-specific binding, in vitro specificity tests of the radioconjugates were performed. Approximately $2 \times 10^{4} \mathrm{UM}-\mathrm{SCC}-74 \mathrm{~B}$ or $3 \times 10^{4}$ HCT116 cells/well were seeded in 48-well plates and incubated for $24 \mathrm{~h}$ prior to the addition of $20 \mathrm{kBq}(25-30 \mathrm{nM})$ of ${ }^{177} \mathrm{Lu}-\mathrm{AbN} 44 \mathrm{v} 6$ or ${ }^{125} \mathrm{I}$-AbN44v6 to each well. In selected wells, $\geq 20$-fold molar excess of unlabeled AbN44v6 was added to the wells to block specific binding. The plates were incubated at $37^{\circ} \mathrm{C}$ for $24 \mathrm{~h}$ before the cells were washed and collected and the binding measured using a 1480 WIZARD gamma well-counter (Wallac Oy, Turku, Finland).

LigandTracer.In order to assess cellular uptake and the retention of the radiolabeled conjugates, LigandTracer experiments were performed. The cells $\left(5-10 \times 10^{5}\right)$ were seeded in $10-\mathrm{cm}$ dishes and incubated for at least $24 \mathrm{~h}$ before running LigandTracer Yellow for ${ }^{177} \mathrm{Lu} /{ }^{131} \mathrm{I}$ or LigandTracer Grey for ${ }^{125} \mathrm{I}$ (Ridgeview Instruments, Vänge, Sweden). Two different concentrations (3 and $10 \mathrm{nM}$ ) of radiolabeled antibodies were added, and the uptake was measured for $90 \mathrm{~min}$ for each concentration before removing the radiolabeled antibodies and replacing the medium to measure the dissociation rate. Analysis was performed using TraceDrawer, version 1.7 (Ridgeview Instruments).

$3 D$ cell culture assays. In order to assess the potential therapeutic effects of the radioconjugates, in vitro therapy experiments were performed on 3D multicellular tumor spheroids, where the growth of tumor spheroids was followed over time. For liquid overlay 3D spheroid formation, $0.15 \mathrm{~g}$ of agarose was dissolved in $10 \mathrm{ml}$ of $\mathrm{PBS}, \mathrm{pH} 7.4$, with $1 \%$ penicillin/streptomycin and $5 \%$ incomplete, serum-free DMEM for liquid overlay of two 96-well plates. For spheroid formation, $1 \times 10^{3}$ UM-SCC-74B and $1-1.5 \times 10^{3}$ HCT116 cells were seeded in 96-well plates precoated with $50 \mu \mathrm{l}$ of agarose. The plates were incubated at $37^{\circ} \mathrm{C}$ in a $5 \% \mathrm{CO}_{2}$ atmosphere for 3 days prior to treatment with either ${ }^{177} \mathrm{Lu} /{ }^{131} \mathrm{I}-\mathrm{AbN} 44 \mathrm{v} 6$ or rituximab. The concentrations of radiolabeled antibodies were added in the range of 10-100 kBq/well (5-140 nM per well for AbN44v6 and 30-111 nM per well for rituximab). The spheroids were followed for 10 days, obtaining images at day 3, 6 and 10 post-treatment using a Canon EOS $700 \mathrm{D}$ digital camera (Canon, Tokyo, Japan) mounted on an inverted Nikon Diaphot-TMD microscope (Nikon, Tokyo, Japan). The spheroid images were analyzed semi-automatically using Image J software version 1.48 (NIH, Bethesda, MD, USA). Outlines of the spheroid shape were drawn and the area of the spheroids was measured. Spheroid volume was then calculated using the formula $\mathrm{V}=4 / 3 \pi \mathrm{r}^{3}$, assuming all spheroids retained a spherical form for volume calculations.

Small animal experiments. The in vivo experiments were carried out in accordance with the current Swedish laws and regulations, designed to comply with ethical guidelines to reduce and refine animal experiments, while maintaining data quality, with permission granted by the Committee of Animal Research Ethics Uppsala. Nu/nu Balb/c mice (female; $n=30$; average weight, $18 \pm 2 \mathrm{~g}$ ) were housed under standard conditions and fed ad libitum. One day prior to tracer injection, the animals were given $1 \%$ sodium iodide in drinking water to block the uptake of free ${ }^{125} \mathrm{I}$ in the thyroid $(24,38-41)$. Each animal was administered approximately $200 \mathrm{kBq}{ }^{177} \mathrm{Lu}-\mathrm{AbN} 44 \mathrm{v} 6$ and $150 \mathrm{kBq}{ }^{125} \mathrm{I}-\mathrm{AbN} 44 \mathrm{v} 6$ in a total of $15 \mu \mathrm{g}$ by an intravenous injection of a volume of $80 \mu 1$ into the tail vein. Doses were selected according to previous studies $(24,42)$. The animals were divided into 6 groups ( $n=5$ per group) and euthanized by an intraperitoneal injection of a mixture of ketamine $(10 \mathrm{mg} / \mathrm{ml})$ and xylazine $(1 \mathrm{mg} / \mathrm{ml})$ at a dose of $0.2 \mathrm{ml}$ per $10 \mathrm{~g}$ of body weight, followed by heart puncture at 3, 6, 24, 48, 96 and $168 \mathrm{~h}$ post-injection. The blood and organs of interest were excised, and the uptake of ${ }^{177} \mathrm{Lu} /{ }^{125} \mathrm{I}-\mathrm{AbN} 44 \mathrm{v} 6$ was measured in a gamma well-counter. Three injection standards of each radioconjugate were included in all gamma well-counter measurements. The uptake of each radionuclide was calculated as a percentage of injected activity/organ, and the tumor/organ ratios were calculated as activity $/ \mathrm{g}_{\text {tumor }}$ divided by activity $/ \mathrm{g}_{\text {organ }}$.

SUV values [(organ activity/organ weight)/(administered activity/animal weight)] were calculated for the selected organs at the above-mentioned time-points. At time zero, SUV was assumed to be zero. For dosimetry, non-decay corrected values (SUVn) were obtained by multiplying the SUV values with the decay curve of ${ }^{177} \mathrm{Lu}$ and ${ }^{131} \mathrm{I}$. The organs were then integrated between 0 and $168 \mathrm{~h}$ using the EXCEL 2007 histogram method. The time interval of $0-168 \mathrm{~h}$ corresponds to approximately one half-life of the nuclides. An estimate of decays remaining after $168 \mathrm{~h}$ was made by integrating an exponential curve passing through the 96 and $168 \mathrm{~h}$ time-points. To calculate the absorbed dose in standard anatomical phantoms, the dosimetry system, Medical Internal Radiation Dose (MIRD), 

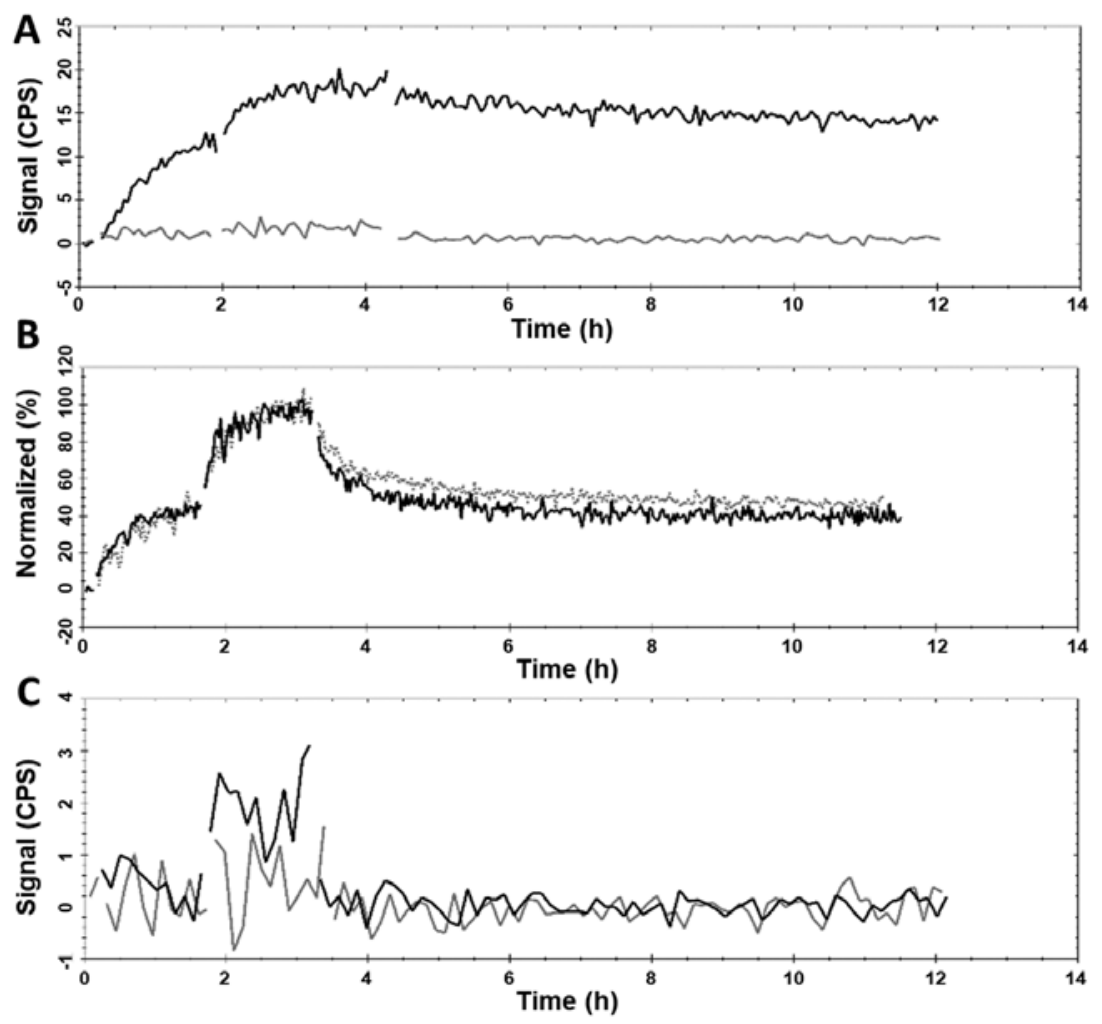

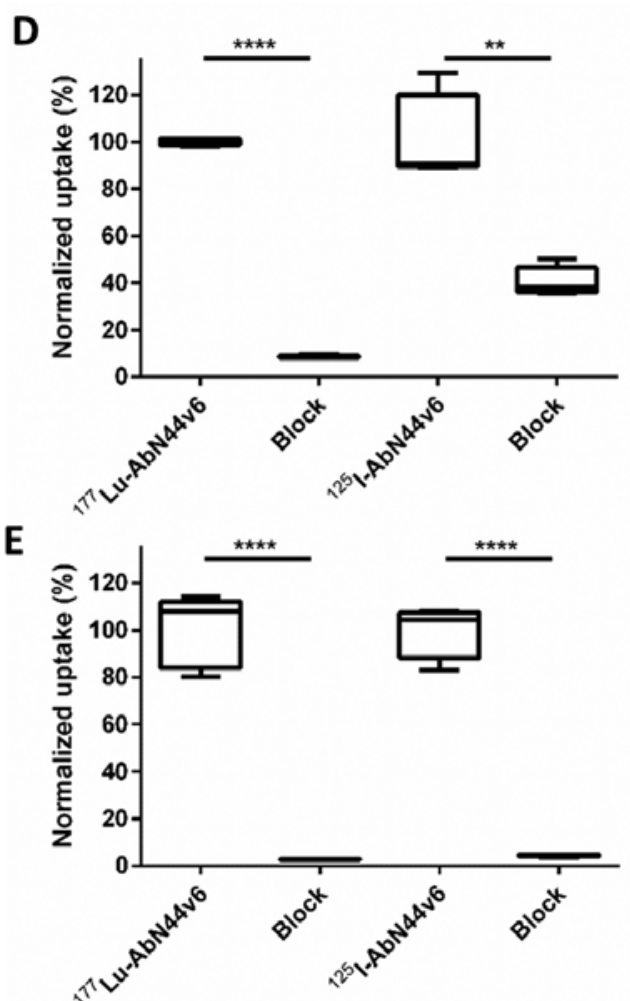

Figure 1. Representative LigandTracer measurements of (A) ${ }^{177} \mathrm{Lu}-\mathrm{AbN} 44 \mathrm{v} 6$ on HCT116 cells (black line) and UM-SCC-74B cells (gray line) plotted as counts per second (CPS). (B) ${ }^{131} \mathrm{I}-\mathrm{AbN} 44 \mathrm{v} 6$ (black) and ${ }^{125} \mathrm{I}-\mathrm{AbN} 44 \mathrm{v} 6$ (gray-dashed line) on the HCT116 cells, normalized to the percentage of maximum binding. (C) ${ }^{131}$ I-rituximab on HCT116 (black line) and UM-SCC-74B cells (gray line). In vitro specificity of radiolabeled AbN44v6 normalized to the total uptake of unblocked samples samples for each radioconjugate of (D) UM-SCC-74B, and (E) HCT116 cells, after $24 \mathrm{~h}$ of incubation with radioconjugate. Please note that the $\mathrm{y}$-axes in (D and E) are normalized to percentage of uptake of unblocked samples for each radioconjugate; $\mathrm{n}=5,{ }^{* * *} \mathrm{p}<0.01$ and ${ }^{* * * * *} \mathrm{p}<0.0001$.

was used for the total number of decays in each main organ. The residence times (RT) were calculated and used as an input to the OLINDA software. The self-dose and the cross-fire dose, as well as the obtained doses in different organs and the effective dose, were calculated using the OLINDA software. To scale the animal data to humans, the SUV values were assumed to be invariant.

Statistical analyses. Statistical analyses were performed using GraphPad Prism software (version 6.2). All data are presented as the means \pm SD unless otherwise stated. The Student's t-test was used to calculate statistical significance in the specific uptake of radiolabeled AbN44v6. Statistical significance was calculated using one-way ANOVA followed by Sidak's multiple comparisons test for defining differences between control, targeted and untargeted radiation in 3D RIT. Values of $\mathrm{p} \leq 0.05, \mathrm{p} \leq 0.01, \mathrm{p} \leq 0.001$ and $\mathrm{p} \leq 0.0001$ were considered to indicate statistically significant differences or highly statistically significant differences, as appropriate.

\section{Results}

Labeling yields and specific activities. For labeling with ${ }^{177} \mathrm{Lu}$, the specific activities varied between 50 and $150 \mathrm{kBq} / \mu \mathrm{g}$ of AbN44v6 with an average yield of $74 \pm 19 \%$. The EDTA challenge resulted in $100 \%$ stability of ${ }^{177} \mathrm{Lu}-\mathrm{AbN} 44 \mathrm{v} 6$ after $48 \mathrm{~h}$ of incubation. For direct radioiodination, the specific activities for ${ }^{125} \mathrm{I}$ varied between 37 and $83 \mathrm{kBq} / \mu \mathrm{g}$ with an average yield of $87 \pm 5 \%$.
Specific activities for ${ }^{131} \mathrm{I}$ were $80-83 \mathrm{kBq} / \mu \mathrm{g}$ with an average yield of $80 \pm 3 \%$. Specific activities for ${ }^{131}$ I-rituximab varied between 30 and $124 \mathrm{kBq} / \mu \mathrm{g}$ with an average yield of $73 \pm 11 \%$.

In vitro specificity is retained following radiolabeling. In order to assess the effects of labeling, the specific binding of conjugates, as well as to verify the CD44v6 expression levels in the cells, LigandTracer analyses and in vitro specificity assays were performed. Furthermore, the binding properties of ${ }^{125}$ I-labeled AbN44v6 were compared to ${ }^{131}$ I-labeled AbN44v6 in order to determine whether ${ }^{125} \mathrm{I}-\mathrm{AbN} 44 \mathrm{v} 6$ could be used as a model for ${ }^{131} \mathrm{I}-\mathrm{AbN} 44 \mathrm{v} 6$.

AbN44v6 was first labeled with ${ }^{177}$ Lu using a CHX-A"-DTPA chelate. A clear cellular uptake was detected by HCT116 cells (a moderate CD44v6-expressing cell line) at both concentrations, followed by a slow dissociation phase of $5 \%$ loss/h (Fig. 1A, black curve). The affinity of ${ }^{177} \mathrm{Lu}-\mathrm{AbN} 44 \mathrm{v} 6$ was calculated using the HCT116 measurements obtained on LigandTracer, resulting in an estimated $\mathrm{K}_{\mathrm{D}}$ in the low (1-10) nanomolar range. The signalto-noise ratio of UM-SCC-74B, a low CD44v6-expressing cell line, was below the detection limit for the LigandTracer instrument (Fig. 1A, gray curve).

Radioiodination of AbN44v6 with either ${ }^{125}$ I (Fig. 1B, black curve) or ${ }^{131} \mathrm{I}$ (Fig. 1B, gray curve) resulted in near identical measurements on HCT116 cells with a clear uptake at both concentrations. A two-phased dissociation, where $\sim 45 \%$ of the bound ligand detached during the first hour, was observed for both radioiodinated conjugates. The second dissociation 
A

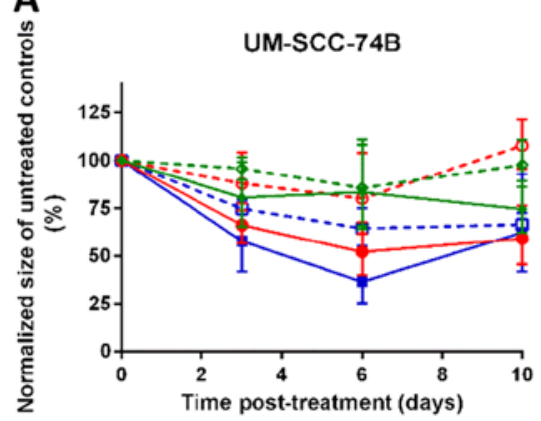

$\rightarrow 10 \mathrm{kBq}{ }^{177} \mathrm{Lu}-\mathrm{AbN} 44 \mathrm{v} 6$

$\rightarrow 50 \mathrm{kBq}{ }^{177} \mathrm{Lu}-\mathrm{AbN} 44 \mathrm{v} 6$

$-100 \mathrm{kBq}{ }^{177} \mathrm{Lu}-\mathrm{AbN} 44 \mathrm{v} 6$

-๑. $10 \mathrm{kBq}{ }^{131} \mathrm{Lu}-\mathrm{AbN} 44 \mathrm{v} 6$

-๑. $50 \mathrm{kBq}{ }^{131} \mathrm{Lu}-\mathrm{AbN} 44 \mathrm{v} 6$

$-\square \cdot 100 \mathrm{kBq}{ }^{131} \mathrm{Lu}-\mathrm{AbN} 44 \mathrm{v} 6$

v6

$100 \mathrm{kBq}$
(rituximab)

B

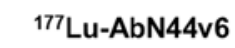

Day 0 Day 6 Day 10
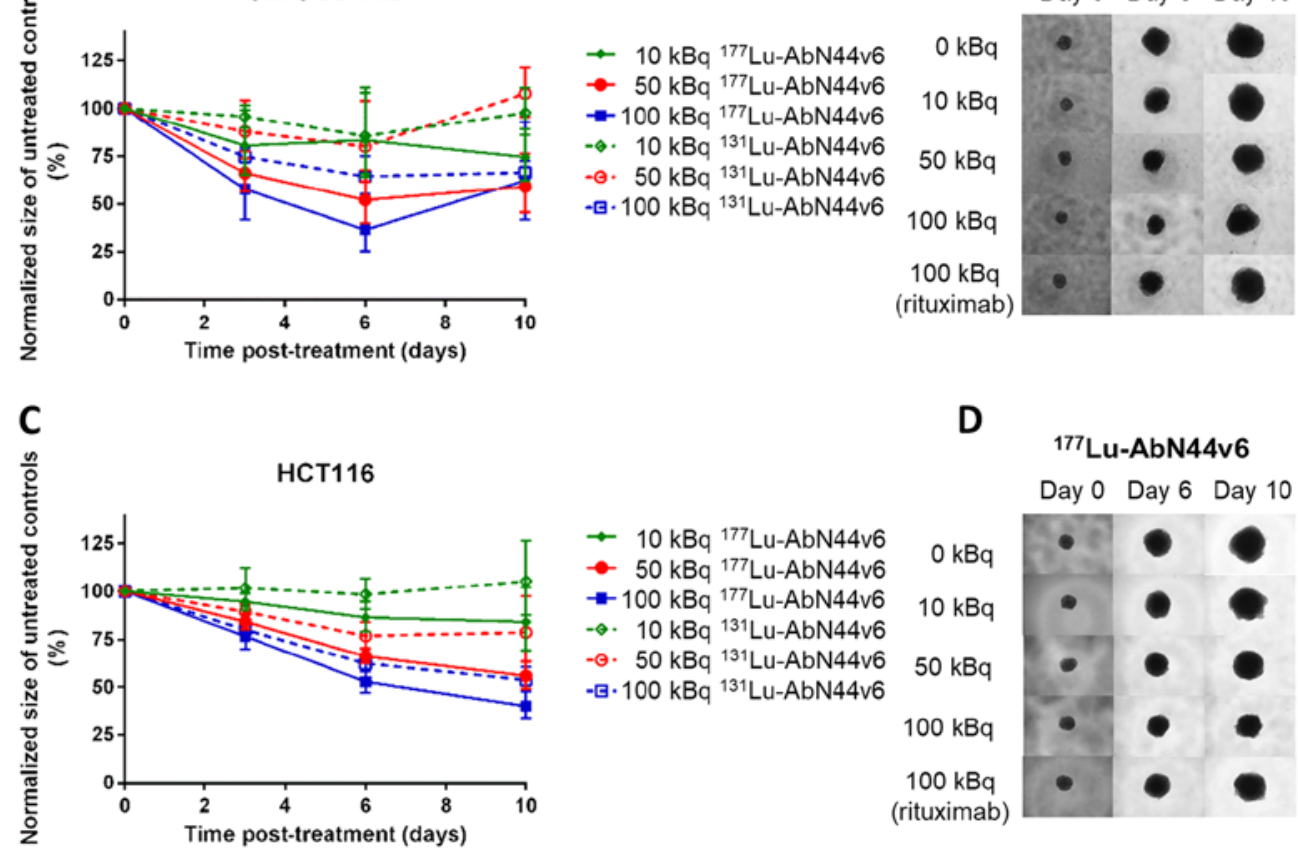

D

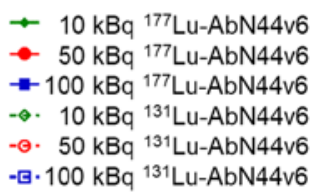
$-100 \mathrm{kBq}{ }^{131} \mathrm{Lu}-\mathrm{AbN} 44 \mathrm{v} 6$

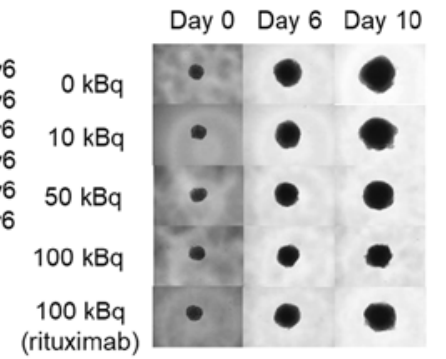

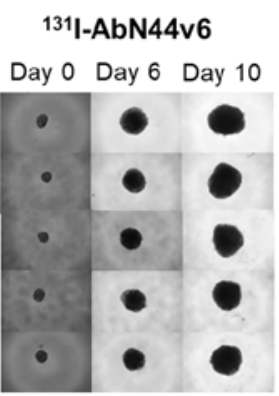

131I-AbN44v6

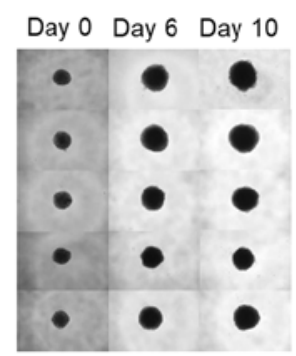

Figure 2. (A) Dose-response of UM-SCC-74B spheroids treated with ${ }^{177} \mathrm{Lu}-\mathrm{AbN} 44 \mathrm{v} 6$ or ${ }^{131} \mathrm{I}-\mathrm{AbN} 44 \mathrm{v} 6$, normalized to the size of untreated controls at each timepoint. (B) Representative images of UM-SCC-74B spheroids treated with 0, 10, 50 or $100 \mathrm{kBq}$ of ${ }^{177} \mathrm{Lu}-\mathrm{AbN} 44 \mathrm{v} 6$ or ${ }^{131} \mathrm{I}-\mathrm{AbN} 44 \mathrm{v} 6$ and $100 \mathrm{kBq}$ of radiolabeled rituximab. (C) Dose-response HCT116 spheroids treated with 0, 10, 50 or $100 \mathrm{kBq}$ of ${ }^{177} \mathrm{Lu}-\mathrm{AbN} 44 \mathrm{v} 6$ or ${ }^{131} \mathrm{I}-\mathrm{AbN} 44 \mathrm{v} 6$, normalized to the size of untreated controls at each time-point. (D) Representative images of HCT116 spheroids treated with ${ }^{177} \mathrm{Lu}-\mathrm{AbN} 44 \mathrm{v} 6$ or ${ }^{131} \mathrm{I}-\mathrm{AbN} 44 \mathrm{v} 6$ and $100 \mathrm{kBq}$ of radiolabeled rituximab. $\mathrm{n} \geq 5$, error bars represent $95 \%$ confidence intervals. Significant growth inhibition was observed for activities $\geq 10 \mathrm{kBq}$ of ${ }^{177} \mathrm{Lu}-\mathrm{AbN} 44 \mathrm{v} 6$ and $\geq 30 \mathrm{kBq}$ of ${ }^{131} \mathrm{I}-\mathrm{AbN} 44 \mathrm{v} 6$ compared to untreated controls. For UM-SCC-74B spheroids, only $100 \mathrm{kBq}$ differed significantly from untreated controls for both radioconjugates.

phase steadied to a slower dissociation of 5 and $12 \%$ loss $/ \mathrm{h}$ for ${ }^{125} \mathrm{I}-\mathrm{AbN} 44 \mathrm{v} 6$ and ${ }^{131} \mathrm{I}-\mathrm{AbN} 44 \mathrm{v} 6$, respectively, which was similar to that of ${ }^{177} \mathrm{Lu}-\mathrm{AbN} 44 \mathrm{v} 6$. Furthermore, the selected negative control for in vitro 3D (spheroid) RIT, rituximab, was labeled with ${ }^{131}$ I and evaluated for binding to both cell lines (Fig. 1C). LigandTracer was unable to detect any binding on either cell line using the ${ }^{131}$ I-rituximab conjugate.

To determine the CD44v6 specificity of the radiolabeled AbN44v6, an in vitro specificity assay using both ${ }^{177} \mathrm{Lu}-\mathrm{AbN} 44 \mathrm{v} 6$ and ${ }^{125} \mathrm{I}-\mathrm{AbN} 44 \mathrm{v} 6$ on UM-SCC-74B and HCT116 cells (Fig. 1D and E) was performed. The uptake in blocked wells with an excess of unlabeled AbN44v6 decreased to an average of 8.6 and $2.8 \%$ for ${ }^{177} \mathrm{Lu}-\mathrm{AbN} 44 \mathrm{v} 6$ on UM-SCC-74B and HCT116 cells, respectively $(\mathrm{p}<0.0001)$. For ${ }^{125} \mathrm{I}-\mathrm{AbN} 44 \mathrm{v} 6$, the uptake in blocked wells with an excess of unlabeled AbN44v6 decreased to an average of 33.9 and $4.4 \%$ for UM-SCC-74B and HCT116 cells, respectively. This result indicated a retained biological function following both labeling procedures and antigen-antibody specificity.

RIT using ${ }^{177} \mathrm{Lu}-A b N 44 v 6$ and ${ }^{131}$ I-AbN44v6 delays spheroid growth in a CD44v6-and activity-dependent manner. The potential therapeutic effects of the radiolabeled antibodies were assessed in in vitro 3D tumor models (spheroid models). By the end of the assay (day 10), only UM-SCC-74B spheroids treated with $100 \mathrm{kBq}$ of the targeted radiation differed significantly to untreated controls $\left(\mathrm{p}<0.05\right.$ and $\mathrm{p}<0.01$ for $\left({ }^{177} \mathrm{Lu}-\right.$ or ${ }^{131} \mathrm{I}$-AbN44v6, respectively) (Fig. 2A and B). A more pronounced therapeutic effect was observed on the HCT116 spheroids, which expressed a higher level of target antigen than the UM-SCC-74B spheroids. Furthermore, increasing activities resulted in more pronounced therapeutic effects (Fig. 2C and D). While the lowest activity $(10 \mathrm{kBq} /$ well $)$ did not result in significant differences in growth progression of HCT116 spheroids of ${ }^{131} \mathrm{I}-\mathrm{AbN} 44 \mathrm{v} 6$, activities exceeding $10 \mathrm{kBq} /$ well differed significantly from the untreated controls for both radioconjugates. Furthermore, HCT116 spheroids treated with $100 \mathrm{kBq}$ of ${ }^{131} \mathrm{I}-\mathrm{AbN} 44 \mathrm{v} 6$ demonstrated a stunted growth throughout the assay, whereas all other treatments started to recover normal growth ratios by the end of the assay (day 10) (data not shown).

Effects on HCT116 spheroid growth is largely caused by targeted radiation. Since unbound radioconjugates present in the medium are expected to contribute to the total dose received by the spheroids, negative controls using radiolabeled rituximab assessed the damage caused by untargeted radiation. The extent of the impaired growth of radiolabeled rituximab differed both between the two cell lines and the two radionuclides. Radiolabeled rituximab accounted for the majority of the growth impairment observed in the UM-SCC-74B spheroids (Fig. 2B). Despite significant growth inhibition between UM-SC-74B controls and the highest added activity of targeted radiation $(100 \mathrm{kBq})$, significance was not obtained between $100 \mathrm{kBq}$ of targeted and non-targeted activity (data not shown). Conversely, the effects on HCT116 spheroid growth were mainly caused by targeted radiation, where significant therapeutic effects of the AbN44v6 radioconjugates compared to radiolabeled rituximab were demonstrated for added activities of $\geq 10 \mathrm{kBq} /$ well and $\geq 30 \mathrm{kBq} /$ well for ${ }^{177} \mathrm{Lu}-\mathrm{AbN} 44 \mathrm{v} 6$ and ${ }^{131} \mathrm{I}-\mathrm{AbN} 44 \mathrm{v} 6$, respectively (Fig. 2D and Table I). 
Table I. Comparisons between therapeutic effects of targeted and untargeted radiation on HCT116 spheroids.

\begin{tabular}{|c|c|c|c|c|c|c|c|}
\hline $\begin{array}{l}\text { HCT116 } \\
\text { Day } 10\end{array}$ & $\begin{array}{c}{ }^{177} \mathrm{Lu}-\text { rituximab } \\
30 \mathrm{kBq}\end{array}$ & $\begin{array}{c}{ }^{177} \mathrm{Lu}-\text { rituximab } \\
50 \mathrm{kBq}\end{array}$ & $\begin{array}{c}{ }^{177} \text { Lu-rituximab } \\
100 \mathrm{kBq}\end{array}$ & $\begin{array}{c}\text { HCT116 } \\
\text { Day } 10\end{array}$ & $\begin{array}{c}{ }^{131} \text { I-rituximab } \\
30 \mathrm{kBq}\end{array}$ & $\begin{array}{c}{ }^{131} \text { I-rituximab } \\
50 \mathrm{kBq}\end{array}$ & $\begin{array}{c}{ }^{131} \text { I-rituximab } \\
100 \mathrm{kBq}\end{array}$ \\
\hline $\begin{array}{l}{ }^{177} \mathrm{Lu}-\mathrm{AbN} 44 \mathrm{v} 6 \\
30 \mathrm{kBq}\end{array}$ & $\mathrm{p}<0.05$ & ns & ns & $\begin{array}{c}{ }^{131} \mathrm{I}-\mathrm{AbN} 44 \mathrm{v} 6 \\
30 \mathrm{kBq}\end{array}$ & ns & ns & ns \\
\hline $\begin{array}{l}{ }^{177} \mathrm{Lu}-\mathrm{AbN} 44 \mathrm{v} 6 \\
50 \mathrm{kBq}\end{array}$ & $\mathrm{n} / \mathrm{a}$ & $\mathrm{p}<0.0001$ & ns & $\begin{array}{c}{ }^{131} \mathrm{I}-\mathrm{AbN} 44 \mathrm{v} 6 \\
50 \mathrm{kBq}\end{array}$ & $\mathrm{n} / \mathrm{a}$ & $\mathrm{p}<0.05$ & ns \\
\hline $\begin{array}{l}{ }^{177} \mathrm{Lu}-\mathrm{AbN} 44 \mathrm{v} 6 \\
70 \mathrm{kBq}\end{array}$ & $\mathrm{n} / \mathrm{a}$ & $\mathrm{n} / \mathrm{a}$ & ns & $\begin{array}{c}{ }^{131} \mathrm{I}-\mathrm{AbN} 44 \mathrm{v} 6 \\
80 \mathrm{kBq}\end{array}$ & $\mathrm{n} / \mathrm{a}$ & $\mathrm{n} / \mathrm{a}$ & $\mathrm{p}<0.05$ \\
\hline $\begin{array}{l}{ }^{177} \mathrm{Lu}-\mathrm{AbN} 44 \mathrm{v} 6 \\
100 \mathrm{kBq}\end{array}$ & $\mathrm{n} / \mathrm{a}$ & $\mathrm{n} / \mathrm{a}$ & $\mathrm{p}<0.001$ & $\begin{array}{c}{ }^{131} \mathrm{I}-\mathrm{AbN} 44 \mathrm{v} 6 \\
100 \mathrm{kBq}\end{array}$ & $\mathrm{n} / \mathrm{a}$ & $\mathrm{n} / \mathrm{a}$ & $\mathrm{p}<0.01$ \\
\hline
\end{tabular}

Comparisons were made between therapeutic effects of targeted and untargeted radiation on HCT116 spheroids at day 10 post-treatment with ${ }^{177} \mathrm{Lu}-\mathrm{AbN} 44 \mathrm{v} 6$ vs. ${ }^{177} \mathrm{Lu}$-rituximab (unspecific) and ${ }^{131} \mathrm{I}-\mathrm{AbN} 44 \mathrm{v} 6$ vs. ${ }^{131}$ I-rituximab. Values of $\mathrm{p} \leq 0.05, \mathrm{p} \leq 0.01$ and $\mathrm{p} \leq 0.001$ were considered to indicate statistically significant differences or highly statistically significant differences, as appropriate. n/a indicates no comparisons, and ns indicates no significance. For UM-SCC-74B, no significant differences were observed between targeted and non-targeted radiation.

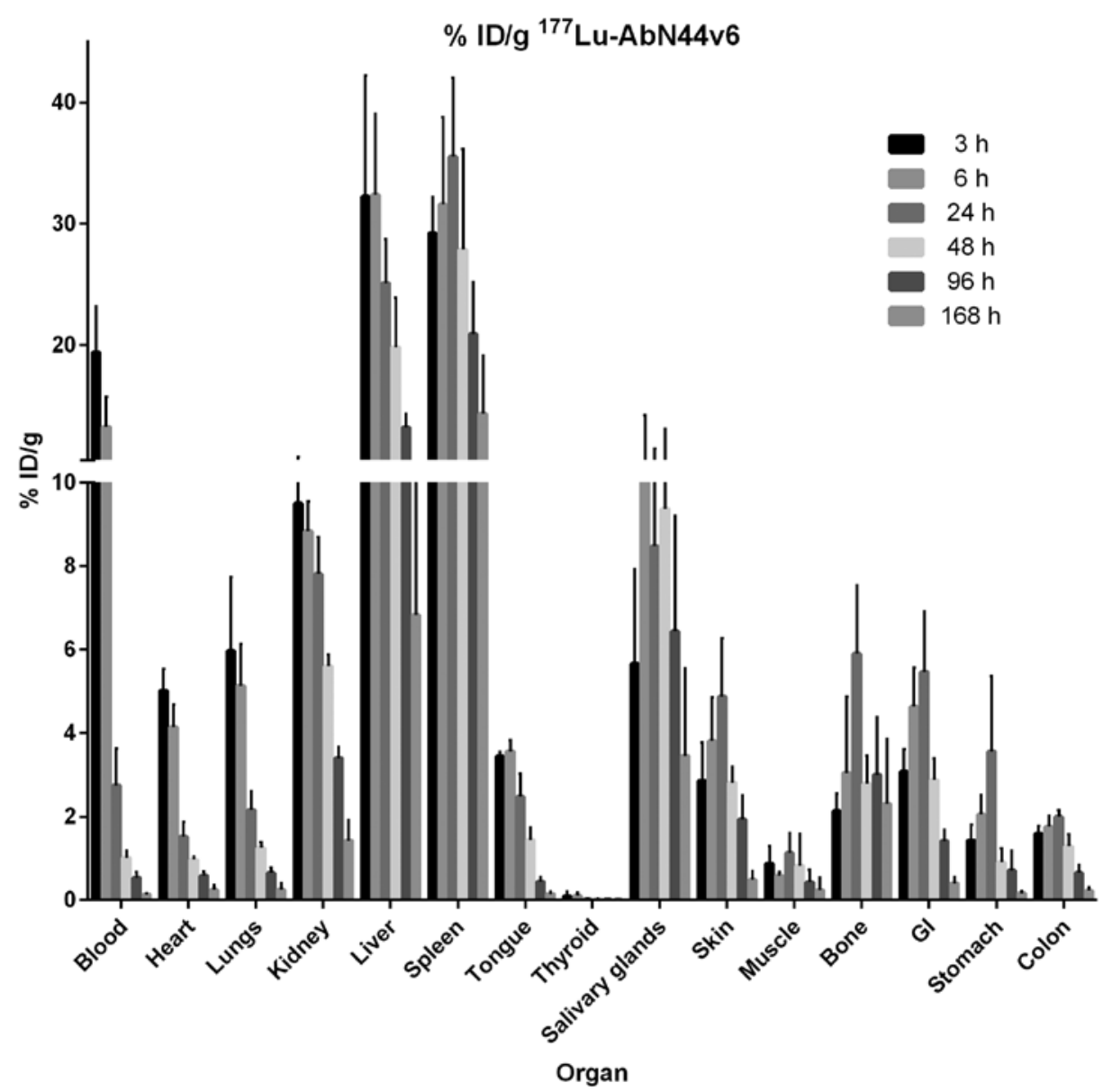

Figure 3. Biodistribution of ${ }^{177} \mathrm{Lu}-\mathrm{AbN} 44 \mathrm{v} 6$ at 3, 6, 24, 48, 96 and $168 \mathrm{~h}$ post-injection, presented as \% ID/g. Error bars represent the means $\pm \mathrm{SD}, \mathrm{n}=5$. Note that the thyroid is presented as \% ID without correcting for weight $(\mathrm{g})$.

In vivo biodistribution of ${ }^{177} \mathrm{Lu}-\mathrm{AbN} 44 \mathrm{v} 6$ and ${ }^{125} \mathrm{I}-\mathrm{AbN} 44 \mathrm{v} 6$ presents similar profiles. The biodistribution of ${ }^{177} \mathrm{Lu}-\mathrm{AbN} 44 \mathrm{v} 6$ can be seen in Fig. 3. Uptake in the dose-limiting organs of interest peaked at $3 \mathrm{~h}$ (kidneys), $6 \mathrm{~h}$ (liver) and $24 \mathrm{~h}$ (spleen) at approximately 10, 32 and $35 \% \mathrm{ID} / \mathrm{g}$, respectively. By the final time-point, the uptake in the kidneys had diminished 10-fold (from 10 to $1 \%$ ). Similarly, at $168 \mathrm{~h}$ post-injection (p.i.), the uptake in the liver and spleen had decreased to approximately 7 


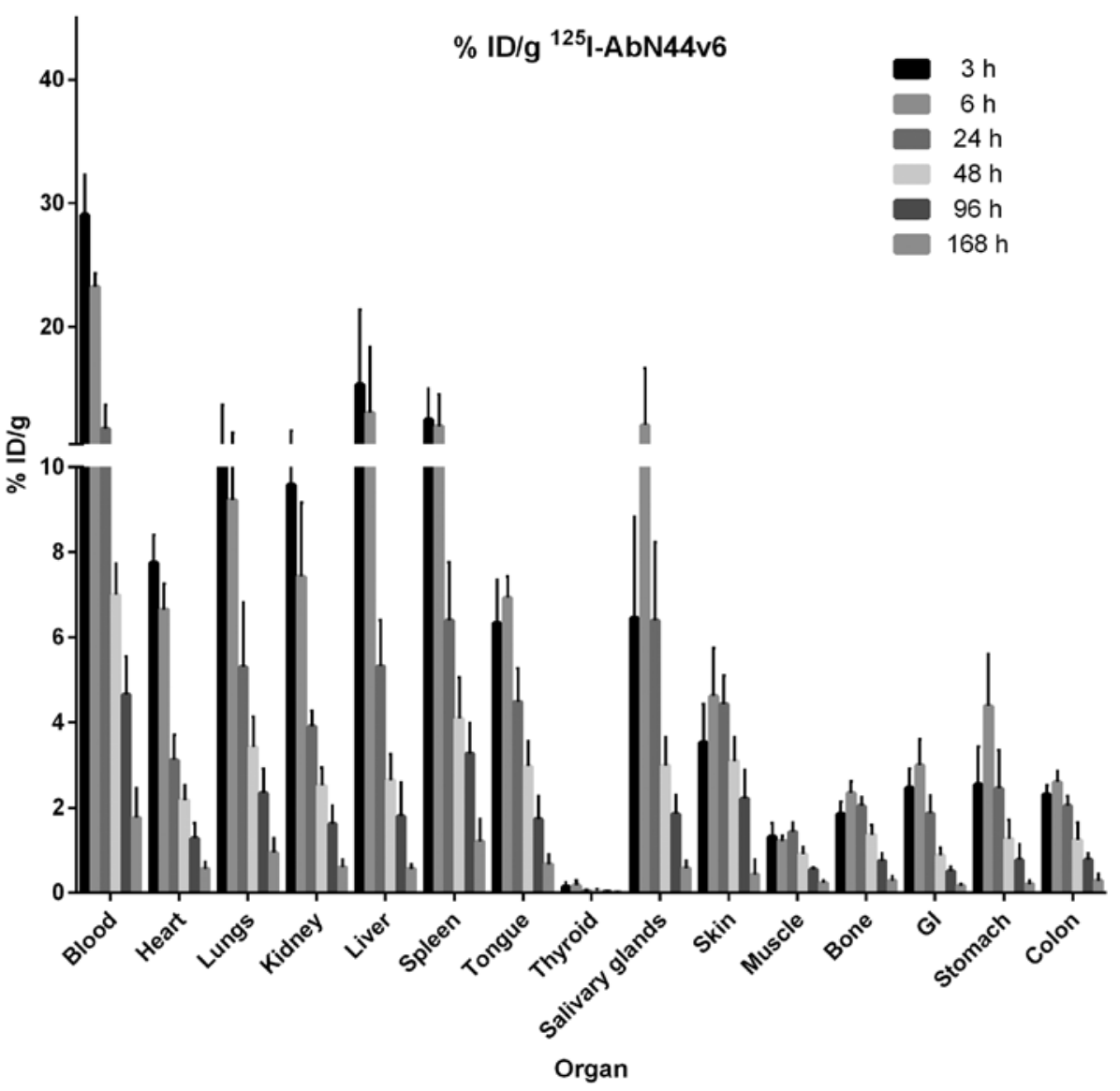

Figure 4. Biodistribution of ${ }^{125} \mathrm{I}-\mathrm{AbN} 44 \mathrm{v} 6$ at 3, 6, 24, 48, 96 and $168 \mathrm{~h}$ post-injection, presented as \% ID/g. Error bars represent the means \pm SD, $\mathrm{n}=5$. Note that the thyroid is presented as \% ID without correcting for weight (g).

and $15 \% \mathrm{ID} / \mathrm{g}$, respectively. As expected, the uptake in the blood peaked at the earliest time-point $(20 \% \mathrm{ID} / \mathrm{g})$, but decreased to $3 \% \mathrm{ID} / \mathrm{g}$ at $24 \mathrm{~h}$ p.i., an $85 \%$ decrease from the uptake $3 \mathrm{~h}$ p.i. At $168 \mathrm{~h}$ p.i., the activity in the blood was almost undetectable. ${ }^{177} \mathrm{Lu}-\mathrm{AbN} 44 \mathrm{v} 6$-uptake in most other organs followed the uptake in the blood and diminished rapidly over time. The biodistribution of ${ }^{125} \mathrm{I}-\mathrm{AbN} 44 \mathrm{v} 6$ can be seen in Fig. 4. A similar pattern was discernible for ${ }^{125} \mathrm{I}-\mathrm{AbN} 44 \mathrm{v} 6$ as for ${ }^{177} \mathrm{Lu}-\mathrm{AbN} 44 \mathrm{v} 6$. The primary difference in biodistribution profiles between the two radioconjugates was the prolonged circulation time of ${ }^{125} \mathrm{I}-\mathrm{AbN} 44 \mathrm{v} 6$. However, the uptake of ${ }^{125} \mathrm{I}-\mathrm{AbN} 44 \mathrm{v} 6$ in the liver and spleen was lower than its ${ }^{177} \mathrm{Lu}$-labeled counterpart, despite the longer circulation time of the radio-iodine conjugate. All organs, including the kidneys, liver and spleen, followed the same pattern of uptake, and the clearance of ${ }^{125} \mathrm{I}-\mathrm{AbN} 44 \mathrm{v} 6$ as observed for the blood, resulting in rapidly decreasing values. The highest uptake of ${ }^{125} \mathrm{I}-\mathrm{AbN} 44 \mathrm{v} 6$ in all assessed organs was detected at either 3 or $6 \mathrm{~h}$ p.i. In dose-limiting organs, the uptake peaked at approximately 10\% (kidneys), $15 \%$ (liver) and $12 \%$ (spleen) at $3 \mathrm{~h}$ p.i., decreasing by $>50 \%$ at $24 \mathrm{~h}$ p.i. and 10 -fold or more by the last time-point.

Integrated non-decay corrected iSUVn values are shown in Table II for ${ }^{177} \mathrm{Lu}$ - and ${ }^{131}$ I-labeled AbN44v6. The calculated residence times were used as input to the OLINDA software (Table III). The sum of the residence times used as an input represented $<10 \%$ of the total amount of administered decays both for ${ }^{177} \mathrm{Lu}$ and ${ }^{131} \mathrm{I}$. An equal amount was entered in the remaining body to compensate for eventual missing activity. The organ doses and effective doses are shown in Tables IV and V for ${ }^{177} \mathrm{Lu}$ - and ${ }^{131} \mathrm{I}$-labeled AbN44v6, respectively. The effective dose was in the order of $0.1 \mathrm{mSv} / \mathrm{MBq}$ for both labels. Critical organs for ${ }^{177} \mathrm{Lu}-\mathrm{AbN} 44 \mathrm{v} 6$ were the liver and spleen, whereas the kidneys and red marrow were onsidered the critical organs for ${ }^{131} \mathrm{I}-\mathrm{AbN} 44 \mathrm{v} 6$.

\section{Discussion}

Molecular imaging of CD44v6-specific antibody fragments has previously been carried out in mouse models and has shown promise as a diagnostic tool superior to golden standard imaging probes $\left({ }^{18} \mathrm{~F}-\mathrm{FDG}\right)$ in tumors overexpressing the receptor $(24,25,42)$. A full-length recombinant human antibody targeting CD44v6 was developed with the aim of shifting the focus to therapeutic applications of this target. The focus of the present study was to evaluate both the characteristics of this novel construct and to assess suitable radioconjugates for potential RIT using AbN44v6.

Throughout the labeling processes, the specificity of ${ }^{177} \mathrm{Lu}$ was retained, resulting in an affinity in the low nanomolar range. Moreover, ${ }^{125}$ I-labeled AbN44v6 presented similar binding capacity and specificity as ${ }^{131}$ I-labeled AbN44v6, allowing the two radioiodine isotopes to be interchangeable throughout both the in vitro and in vivo experiments. These results are consistent with those of previous studies where surrogate radio-iodine isotopes have been used in early assessments (43). Furthermore, we were able to verify in vitro that although both 
Table II. Integrated non-decay corrected SUV values (iSUVn) of ${ }^{177} \mathrm{Lu}$ and ${ }^{131} \mathrm{I}$ as labels.

\begin{tabular}{lcc}
\hline iSUVn Organ & ${ }^{177}$ Lu-AbN44v6 & ${ }^{131}$ I-AbN44v6 \\
\hline Blood & 53.19 & 135.448 \\
Heart & 25.90 & 82.37 \\
Lungs & 32.06 & 93.99 \\
Kidneys & 108.47 & 98.08 \\
Liver & 396.98 & 80.42 \\
Spleen & 644.1 & 135.48 \\
Tongue & 28.48 & 82.37 \\
Salivary glands & 182.60 & 98.08 \\
Skin & 54.05 & 80.42 \\
Muscle & 14.86 & 24.36 \\
Bone & 83.32 & 35.00 \\
GI & 56.30 & 27.82 \\
Stomach & 27.32 & 38.79 \\
Gallbladder & 63.43 & 41.60 \\
Bladder & 98.99 & 163.41 \\
Colon & 23.82 & 37.28 \\
Feces & 40.43 & 9.50 \\
Brain & 1.15 & 4.78 \\
\hline
\end{tabular}

iSUVn values are presented in hours; GI, gastrointestinal.

cell lines expressed the CD44v6 antigen (Fig. 1) and that the HCT116 cell line clearly expressed more CD44v6-antigens compared to the UM-SCC-74B cells (Fig. 1A, D and E). Thus, a functioning RIT conjugate targeting CD44v6 would be expected to demonstrate higher cytotoxic effects on the HCT116 spheroids (moderate CD44v6 expression) than the UM-SCC-74B spheroids (low CD44v6 expression). This hypothesis was verified in the $3 \mathrm{D}$ therapy assays, where specific RIT effects were demonstrated for HCT116 spheroids for both radioconjugates, whereas the main reason behind the impaired growth of the low CD44v6-expressing spheroids was due to the mere presence of beta emitters in the cell medium (Fig. 2 and Table I). The greater effect of the targeted radiation on the moderate CD44v6-expressing cell line exemplifies the advantages of targeted therapy and offers hope for future utilization of radiolabeled AbN44v6 for RIT. In other words, the CD44v6 expression normally associated with aggressive disease, as well as radio- and chemo-resistance, may be exploited through RIT to impair the growth of moderate-to-high-CD44v6-expressing tumors.

The in vivo biodistribution of the two radioconjugates resulted in very similar profiles. However, the ${ }^{177} \mathrm{Lu}$-labeled tracer demonstrated a greater uptake in the liver and spleen than ${ }^{125} \mathrm{I}-\mathrm{AbN} 44 \mathrm{v} 6$. The uptake of ${ }^{177} \mathrm{Lu}-\mathrm{AbN} 44 \mathrm{v} 6$ in the liver was twice as high ( 32 vs. $13 \%$ at $6 \mathrm{~h}$ p.i.) and 6-fold greater in the spleen (35 vs. $6 \%$ at $24 \mathrm{~h}$ p.i.) compared with ${ }^{125} \mathrm{I}-\mathrm{AbN} 44 \mathrm{v} 6$. These observations are also in agreement with those reported in the literature when iodine and radiometals are compared (44). The observed increase in uptake of ${ }^{177} \mathrm{Lu}$ in the liver may be a result of antibody clearance or exchange with iron-binding protein or a combination of both processes (44).
Table III. Calculated residence times (RT) in hours as the input to OLINDA using ${ }^{177} \mathrm{Lu}$ and ${ }^{131} \mathrm{I}$ as labels.

\begin{tabular}{|c|c|c|}
\hline iSUVn Organ & ${ }^{177} \mathrm{Lu}-\mathrm{AbN} 44 \mathrm{v} 6$ & ${ }^{131} \mathrm{I}-\mathrm{AbN} 44 \mathrm{v} 6$ \\
\hline Adrenals & 0.0000 & 0.0000 \\
\hline Brain & 0.022 & 0.0922 \\
\hline Breasts & 0.0000 & 0.0000 \\
\hline GB content & 0.009 & 0.0056 \\
\hline LLI content & 0.0000 & 0.1113 \\
\hline SI content & 0.0000 & 0.2555 \\
\hline Stomach content & 0.517 & 0.0000 \\
\hline ULI content & 0.0000 & 0.1113 \\
\hline Heart content & 3.61 & 0.9 \\
\hline Heart wall & 0.0000 & 0.35 \\
\hline Kidneys & 0.44 & 0.40 \\
\hline Liver & 10.3 & 2.0841 \\
\hline Lungs & 0.43 & 1.28 \\
\hline Muscle & 5.65 & 9.3 \\
\hline Ovaries & 0.0000 & 0.0000 \\
\hline Pancreas & 0.0000 & 0.0000 \\
\hline Red marrow & 0.0000 & 0.0000 \\
\hline Cortical bone & 0.0000 & 0.0000 \\
\hline Trabecular bone & 0.0000 & 0.0000 \\
\hline Spleen & 1.6 & 0.34 \\
\hline Testes & 0.0000 & 0.0000 \\
\hline Thymus & 0.0000 & 0.0000 \\
\hline Thyroid & 0.0000 & 0.0264 \\
\hline UB content & 0.0000 & 0.105 \\
\hline Uterus & 0.0000 & 0.0000 \\
\hline Rem body & 24 & 20 \\
\hline
\end{tabular}

GI content, gall bladder content; LLI content, lower large intestinal content; SI content, small intestinal content; ULI content, upper large intestinal content; UB content, urinary bladder content; Rem body, remaining body.

Of note, ${ }^{177} \mathrm{Lu}-\mathrm{AbN} 44 \mathrm{v} 6$ was cleared from the bloodstream more rapidly than ${ }^{125} \mathrm{I}-\mathrm{AbN} 44 \mathrm{v} 6$. Potential explanations for the more rapid clearance of ${ }^{177} \mathrm{Lu}-\mathrm{AbN} 44 \mathrm{v} 6$ could be lower in vivo stability, or a higher amount of aggregation of ${ }^{177} \mathrm{Lu}-\mathrm{AbN} 44 \mathrm{v} 6$ than for ${ }^{125} \mathrm{I}-\mathrm{AbN} 44 \mathrm{v} 6$, resulting in an increase in the effective size and, thus, clearance from the circulation via a size-dependent mechanism (45). This needs to be further assessed in future studies. Furthermore, despite the slower clearance from circulation, ${ }^{125} \mathrm{I}-\mathrm{AbN} 44 \mathrm{v} 6$ uptake in all organs peaked at $3 \mathrm{~h}$ or $6 \mathrm{~h}$ p.i., with rapid clearance over time even in high perfusion organs (i.e., kidneys, liver and spleen). The uptake of ${ }^{177} \mathrm{Lu}-\mathrm{AbN} 44 \mathrm{v} 6$ however, despite a more rapid clearance from circulation, peaked at $24 \mathrm{~h}$ p.i. in a selection of organs (spleen, skin, bone, GI and stomach). These observations correlate with the previously obtained results of the in vivo biodistribution of the CD44v6-targeting Fab AbD15179 (42), in which the ${ }^{125}$ I-labeled compounds demonstrated lower uptake and faster clearance from organs compared to radiometal-labeled conjugates. The reason for this has been suggested to be dehalogenation of the 
Table IV. Effective doses (ED) of ${ }^{177} \mathrm{Lu}$ as label in $\mathrm{mSv} / \mathrm{MBq}$ for beta, photon, total and ED.

\begin{tabular}{|c|c|c|c|c|}
\hline Target organ & Beta & Photon & Total & ED Cont. \\
\hline Adrenals & $2.88 \mathrm{E}-02$ & $1.05 \mathrm{E}-02$ & $3.93 \mathrm{E}-02$ & $9.83 \mathrm{E}-05$ \\
\hline Brain & $1.32 \mathrm{E}-03$ & $1.65 \mathrm{E}-03$ & $2.97 \mathrm{E}-03$ & 7.42E-06 \\
\hline Breasts & $2.88 \mathrm{E}-0$ & $4.10 \mathrm{E}-03$ & $3.29 \mathrm{E}-02$ & $1.64 \mathrm{E}-03$ \\
\hline $\begin{array}{l}\text { Lower large } \\
\text { intestinal wall }\end{array}$ & $2.88 \mathrm{E}-02$ & $5.05 \mathrm{E}-03$ & $3.38 \mathrm{E}-02$ & $4.06 \mathrm{E}-03$ \\
\hline Small intestine & $2.88 \mathrm{E}-02$ & $6.56 \mathrm{E}-03$ & $3.54 \mathrm{E}-02$ & 8.84E-05 \\
\hline Stomach wall & $1.13 \mathrm{E}-01$ & $8.86 \mathrm{E}-03$ & $1.22 \mathrm{E}-01$ & $1.46 \mathrm{E}-02$ \\
\hline $\begin{array}{l}\text { Upper large } \\
\text { intestinal wall }\end{array}$ & $2.88 \mathrm{E}-02$ & $7.03 \mathrm{E}-03$ & $3.58 \mathrm{E}-02$ & $8.96 \mathrm{E}-05$ \\
\hline Kidneys & $1.25 \mathrm{E}-01$ & $9.59 \mathrm{E}-03$ & $1.35 \mathrm{E}-01$ & $3.36 \mathrm{E}-04$ \\
\hline Liver & $4.58 \mathrm{E}-01$ & $2.26 \mathrm{E}-02$ & $4.80 \mathrm{E}-01$ & $2.40 \mathrm{E}-02$ \\
\hline Lungs & $3.65 \mathrm{E}-02$ & $7.27 \mathrm{E}-03$ & 4.38E-02 & $5.25 \mathrm{E}-03$ \\
\hline Muscle & $1.71 \mathrm{E}-02$ & 4.38E-03 & $2.15 \mathrm{E}-02$ & 5.38E-05 \\
\hline Ovaries & $2.88 \mathrm{E}-02$ & $5.49 \mathrm{E}-03$ & $3.43 \mathrm{E}-02$ & $6.86 \mathrm{E}-03$ \\
\hline Pancreas & $2.88 \mathrm{E}-02$ & $1.19 \mathrm{E}-02$ & 4.07E-02 & $1.02 \mathrm{E}-04$ \\
\hline Red marrow & $2.13 \mathrm{E}-02$ & $5.12 \mathrm{E}-03$ & $2.64 \mathrm{E}-02$ & $3.17 \mathrm{E}-03$ \\
\hline Osteogenic cells & $9.25 \mathrm{E}-02$ & $8.72 \mathrm{E}-03$ & $1.01 \mathrm{E}-01$ & $1.01 \mathrm{E}-03$ \\
\hline Skin & $2.88 \mathrm{E}-02$ & $2.51 \mathrm{E}-03$ & $3.13 \mathrm{E}-02$ & $3.13 \mathrm{E}-04$ \\
\hline Spleen & $7.42 \mathrm{E}-01$ & $1.93 \mathrm{E}-02$ & 7.62E-01 & $1.90 \mathrm{E}-02$ \\
\hline Thymus & $2.88 \mathrm{E}-02$ & $7.31 \mathrm{E}-03$ & $3.61 \mathrm{E}-02$ & $9.03 \mathrm{E}-05$ \\
\hline $\begin{array}{l}\text { Urinary bladder } \\
\text { wall }\end{array}$ & $2.88 \mathrm{E}-02$ & $4.62 \mathrm{E}-03$ & $3.34 \mathrm{E}-02$ & $1.67 \mathrm{E}-03$ \\
\hline Uterus & $2.88 \mathrm{E}-02$ & $5.51 \mathrm{E}-03$ & $3.43 \mathrm{E}-02$ & $8.58 \mathrm{E}-05$ \\
\hline
\end{tabular}

radioiodinated protein or exchange of the radiometal into ironbinding proteins (44).

When comparing the biodistribution data in the present study with the previously obtained data from the smaller CD44v6-targeting Fab-fragment (42) several additional observations can be made. First, the uptake in the liver and spleen of the smaller radiolabeled Fab AbD15179 was generally greater than the uptake of the full-length tracer, AbN44v6. Second, the uptake in kidneys of ${ }^{111} \mathrm{In}$-AbD15179 was 10 -fold that of either ${ }^{177} \mathrm{Lu}-\mathrm{AbN} 44 \mathrm{v} 6$ or ${ }^{125} \mathrm{I}-\mathrm{AbN} 44 \mathrm{v} 6$ at the earliest time-points and remained elevated, whereas the uptake of the full-length AbN44v6 radioconjugates rapidly decreased. The reduced kidney uptake was expected, given the size of AbN44v6 is above the glomerular filtration size threshold, whereas the size of AbD15179 is not (46). These findings emphasize the importance of tracer size in regard to uptake in dose-limiting organs such as the kidneys.

Dosimetric calculations were in agreement with the biodistribution data (Tables IV and V). The uncertainty in calculating absorbed dose in humans based on an animal model is of course large. However, it is an FDA requirement that the 'first in human' dose should be based on a pre-clinical animal model to ensure a safe entry into phase I clinical trials. Several methods to scale the absorbed dose can found in the literature. In this study, we used the most preferred one, usually referred to as the $\% \mathrm{~kg} / \mathrm{g}$ method (47). The model is usually formulated in a different way, but it is easily seen, by rearranging the parameters and the units,
Table V. Effective doses (ED) of ${ }^{131} \mathrm{I}$ as label in $\mathrm{mSv} / \mathrm{MBq}$ for beta, photon, total and ED.

\begin{tabular}{|c|c|c|c|c|}
\hline Target organ & Beta & Photon & Total & ED Cont. \\
\hline Adrenals & $3.01 \mathrm{E}-02$ & $5.77 \mathrm{E}-02$ & 8.78E-02 & 2.19E-04 \\
\hline Brain & $7.20 \mathrm{E}-03$ & $1.63 \mathrm{E}-02$ & $2.35 \mathrm{E}-02$ & 5.88E-05 \\
\hline Breasts & $3.01 \mathrm{E}-02$ & $3.18 \mathrm{E}-02$ & $6.19 \mathrm{E}-02$ & $3.10 \mathrm{E}-03$ \\
\hline $\begin{array}{l}\text { Lower large } \\
\text { intestinal wall }\end{array}$ & 7.33E-02 & 4.95E-02 & $1.23 \mathrm{E}-01$ & $1.47 \mathrm{E}-02$ \\
\hline Small intestine & $6.36 \mathrm{E}-02$ & $5.30 \mathrm{E}-02$ & $1.17 \mathrm{E}-01$ & 2.91E-04 \\
\hline Stomach wall & $3.01 \mathrm{E}-02$ & $5.10 \mathrm{E}-02$ & $8.11 \mathrm{E}-02$ & $9.73 \mathrm{E}-03$ \\
\hline $\begin{array}{l}\text { Upper large } \\
\text { intestinal wall }\end{array}$ & $5.67 \mathrm{E}-02$ & $5.18 \mathrm{E}-02$ & $1.09 \mathrm{E}-01$ & $2.71 \mathrm{E}-04$ \\
\hline Kidneys & $1.48 \mathrm{E}-01$ & $6.23 \mathrm{E}-02$ & $2.11 \mathrm{E}-01$ & 5.27E-04 \\
\hline Liver & $1.21 \mathrm{E}-01$ & $6.94 \mathrm{E}-02$ & $1.90 \mathrm{E}-01$ & $9.52 \mathrm{E}-03$ \\
\hline Lungs & $1.42 \mathrm{E}-01$ & $5.18 \mathrm{E}-02$ & $1.94 \mathrm{E}-01$ & 2.33E-02 \\
\hline Muscle & $3.69 \mathrm{E}-02$ & $3.68 \mathrm{E}-02$ & 7.37E-02 & $1.84 \mathrm{E}-04$ \\
\hline Ovaries & $3.01 \mathrm{E}-02$ & $5.11 \mathrm{E}-02$ & $8.12 \mathrm{E}-02$ & $1.62 \mathrm{E}-02$ \\
\hline Pancreas & $3.01 \mathrm{E}-02$ & $6.17 \mathrm{E}-02$ & $9.18 \mathrm{E}-02$ & 2.30E-04 \\
\hline Red marrow & $2.16 \mathrm{E}-02$ & 4.30E-02 & $6.46 \mathrm{E}-02$ & $7.75 \mathrm{E}-03$ \\
\hline Osteogenic cells & $7.70 \mathrm{E}-02$ & $5.09 \mathrm{E}-02$ & $1.28 \mathrm{E}-01$ & $1.28 \mathrm{E}-03$ \\
\hline Skin & $3.01 \mathrm{E}-02$ & 2.34E-02 & $5.35 \mathrm{E}-02$ & 5.35E-04 \\
\hline Spleen & $2.06 \mathrm{E}-01$ & 7.16E-02 & $2.78 \mathrm{E}-01$ & 6.94E-03 \\
\hline Thymus & $3.01 \mathrm{E}-02$ & $4.83 \mathrm{E}-02$ & 7.84E-02 & $1.96 \mathrm{E}-04$ \\
\hline $\begin{array}{l}\text { Urinary bladder } \\
\text { wall }\end{array}$ & $5.77 \mathrm{E}-02$ & 4.61E-02 & $1.04 \mathrm{E}-01$ & 5.19E-03 \\
\hline Uterus & $3.01 \mathrm{E}-02$ & $5.15 \mathrm{E}-02$ & 8.17E-02 & $2.04 \mathrm{E}-04$ \\
\hline
\end{tabular}

that it is equivalent with our assumption that the SUV values are invariant. The highest organ doses with the ${ }^{177} \mathrm{Lu}$-label were found in the liver $(0.48 \mathrm{mSv} / \mathrm{MBq})$, kidneys $(0.14 \mathrm{mSv} / \mathrm{MBq})$, lungs $(0.044 \mathrm{mSv} / \mathrm{MBq})$ and the spleen $(0.76 \mathrm{mSv} / \mathrm{MBq})$. Corresponding values for the ${ }^{131} \mathrm{I}$-label were in the liver $(0.19 \mathrm{mSv} / \mathrm{MBq})$, kidneys $(0.21 \mathrm{mSv} / \mathrm{MBq})$, lungs $(0.19 \mathrm{mSv} / \mathrm{MBq})$ and the spleen $(0.27 \mathrm{mSv} / \mathrm{MBq})$. Critical organs for the ${ }^{177} \mathrm{Lu}$-label were the liver and to some extent the spleen, while the kidneys have to be considered a critical organ for the ${ }^{131} \mathrm{I}$-label. Red marrow doses calculated using OLINDA are mainly cross-fire doses and are, due to this, fairly low. The higher dose for the ${ }^{131} \mathrm{I}$-label is mainly due to the higher gamma abundance in the ${ }^{131} \mathrm{I}$ decay. An estimate of the self-dose has to be calculated differently and more information on the behavior of the antibody is needed. This information would help determine whether AbN44v6 is only passively distributed in the blood or if it to some extent binds to the red marrow. Most likely, a substantial part of the red marrow dose will be due to beta radiation from the blood. Since the integrated blood curve is 2.5 times larger for the ${ }^{131}$ I-label compared to the ${ }^{177} \mathrm{Lu}$-label, the red marrow dose for the ${ }^{131} \mathrm{I}$-label will substantially increase and may be the limiting dose. The effective dose was in the order of $0.1 \mathrm{mSv} / \mathrm{MBq}$ for both labels and the somewhat higher ${ }^{131} \mathrm{I}-$ value is mainly to more gamma cross-fire. The results verify the possibility of utilizing both AbN44v6-radioconjugates in future studies and offers the option of choosing the most suitable radionuclide for each patient. Thus, for both conju- 
gates, the doses were relatively low, with promising kinetics peaking $\sim 24 \mathrm{~h}$ p.i. and a relatively fast clearance of activity. Consequently, the potential for RIT seems promising for both conjugates. We have previously demonstrated CD44v6specific tumor targeting in vivo using this construct in other formats $(24,42)$. Consequently, in vivo targeting of tumors expressing high amounts of CD44v6 should hopefully result in distinct AbN44v6 tumor uptake, with a slower clearance from tumors compared to nonspecific organs. However, this remains to be verified in a future in vivo tumor model and is thus outside the scope of this article. Of note, as AbN44v6 does not cross-react with murine CD44v6. Consequently the uptake in normal murine organs is not due to specific CD44v6 uptake (42). Thus, it is not possible to fully extrapolate the results of the dosimetry and biodistribution study to humans. However, since factors such as size, charge, lipophilicity and selected radionuclide of the targeting agent are crucial to the clearance route and potential offtarget effects, the in vivo study still contributed important knowledge. This, together with the fact that previous studies using anti-CD44v6 antibodies in humans, has demonstrated that specific CD44v6-binding effects do not pose a problem normal tissues (26) is very promising for future studies.

In conclusion, we have demonstrated that AbN44v6 can be radiolabeled with ${ }^{177} \mathrm{Lu},{ }^{125} \mathrm{I}$ and ${ }^{131} \mathrm{I}$ and that the radioconjugates bind specifically and with high affinity to CD44v6. In vitro RIT in 3D models resulted in spheroid growth inhibition in a CD44v6-specific and dose-dependent manner for both ${ }^{177} \mathrm{Lu}-\mathrm{AbN} 44 \mathrm{v} 6$ and ${ }^{131} \mathrm{I}-\mathrm{AbN} 44 \mathrm{v} 6$, emphasizing the promise of AbN44v6 in RIT. The in vivo results were encouraging, with relatively low doses to normal tissue, promising kinetics and a relatively fast clearance of activity for both conjugates. However, future studies in mouse xenografts, as well as further optimizations of labeling and purification procedures and a more extensive evaluation of the in vivo stability of both radioconjugates, are needed. Nevertheless, the specific therapeutic effects observed with radiolabeled AbN44v6 in the in vitro 3D tumor models, combined with the beneficial biodistribution and dosimetry in vivo, makes $\mathrm{AbN} 44 \mathrm{v} 6$ a promising future candidate for RIT.

\section{Acknowledgements}

The authors would like to thank Veronika Wingstedt for her assistance with the animal injections.

\section{Funding}

The authors gratefully acknowledge support from the Swedish Research Council and the Swedish Cancer Society.

\section{Availability of data and materials}

The analyzed data sets generated during the study are available from the corresponding author on reasonable request.

\section{Authors' contributions}

ACM designed the study with MN and carried out the majority of the experimental work, data analyses and drafted the manu- script. DS contributed to the experimental work and drafting, as well as revising the manuscript. AKH contributed to the experimental work and revising the manuscript. HL contributed to the design of the study and performed data analyses, as well as drafting and revising the manuscript. $\mathrm{MN}$ designed the study and contributed to data analyses, as well as drafting and revising the manuscript.

\section{Ethics approval and consent to participate}

The in vivo experiments were carried out in accordance with the current Swedish laws and regulations, designed to comply with ethical guidelines to reduce and refine animal experiments, while maintaining data quality, with permission granted by the Committee of Animal Research Ethics Uppsala.

\section{Consent for publication}

Not applicable.

\section{Competing interests}

The authors declare that they have no competing interests.

\section{References}

1. Schmidt F and Efferth T: Tumor heterogeneity, single-cell sequencing, and drug resistance. Pharmaceuticals (Basel) 9: 33, 2016.

2. Zukotynski K, Jadvar H, Capala J and Fahey F: Targeted radionuclide therapy: Practical applications and future prospects. Biomark Cancer 8 (Suppl 2): 35-38, 2016.

3. Otte A: Neuroendocrine tumors: Peptide receptors radionuclide therapy (PRRT). Hell J Nucl Med 19: 182, 2016.

4. Dash A, Knapp FF and Pillai MR: Targeted radionuclide therapy - an overview. Curr Radiopharm 6: 152-180, 2013.

5. Sneath RJ and Mangham DC: The normal structure and function of CD44 and its role in neoplasia. Mol Pathol 51: 191-200, 1998.

6. Todaro M, Gaggianesi M, Catalano V, Benfante A, Iovino F Biffoni M, Apuzzo T, Sperduti I, Volpe S, Cocorullo G, et al: CD44v6 is a marker of constitutive and reprogrammed cancer stem cells driving colon cancer metastasis. Cell Stem Cell 14: 342-356, 2014.

7. Shi J, Zhou Z, Di W and Li N: Correlation of CD44v6 expression with ovarian cancer progression and recurrence. BMC Cancer 13: 182, 2013.

8. Tjhay F, Motohara T, Tayama S, Narantuya D, Fujimoto K, Guo J, Sakaguchi I, Honda R, Tashiro H and Katabuchi H: CD44 variant 6 is correlated with peritoneal dissemination and poor prognosis in patients with advanced epithelial ovarian cancer. Cancer Sci 106: 1421-1428, 2015.

9. Ni J, Cozzi PJ, Hao JL, Beretov J, Chang L, Duan W, Shigdar S, Delprado WJ, Graham PH, Bucci J, et al: CD44 variant 6 is associated with prostate cancer metastasis and chemo-/radioresistance. Prostate 74: 602-617, 2014.

10. Wu XJ, Li XD, Zhang H, Zhang X, Ning ZH, Yin YM and Tian Y: Clinical significance of CD44s, CD44v3 and CD44v6 in breast cancer. J Int Med Res 43: 173-179, 2015.

11. Afify A, Durbin-Johnson B, Virdi A and Jess H: The expression of CD44v6 in colon: From normal to malignant. Ann Diagn Pathol 20: 19-23, 2016.

12. Fox SB, Fawcett J, Jackson DG, Collins I, Gatter KC, Harris AL, Gearing A and Simmons DL: Normal human tissues, in addition to some tumors, express multiple different CD44 isoforms. Cancer Res 54: 4539-4546, 1994.

13. Heider KH, Mulder JW, Ostermann E, Susani S, Patzelt E, Pals ST and Adolf GR: Splice variants of the cell surface glycoprotein CD44 associated with metastatic tumour cells are expressed in normal tissues of humans and cynomolgus monkeys. Eur J Cancer 31A: 2385-2391, 1995. 
14. Lv L, Liu HG, Dong SY, Yang F, Wang QX, Guo GL, Pan YF and Zhang XH: Upregulation of CD44v6 contributes to acquired chemoresistance via the modulation of autophagy in colon cancer SW480 cells. Tumour Biol 37: 8811-8824, 2016.

15. Bellerby R, Smith C, Kyme S, Gee J, Günthert U, Green A, Rakha E, Barrett-Lee P and Hiscox S: Overexpression of specific CD44 isoforms is associated with aggressive cell features in acquired endocrine resistance. Front Oncol 6: 145, 2016.

16. Saito $S$, Okabe $H$, Watanabe $M$, Ishimoto T, Iwatsuki M, Baba $Y$, Tanaka Y, Kurashige J, Miyamoto Y and Baba H: CD44v6 expression is related to mesenchymal phenotype and poor prognosis in patients with colorectal cancer. Oncol Rep 29: 1570-1578, 2013

17. Omran OM and Ata HS: CD44s and CD44v6 in diagnosis and prognosis of human bladder cancer. Ultrastruct Pathol 36: 145-152, 2012.

18. Shiozaki M, Ishiguro H, Kuwabara Y, Kimura M, Mitsui A, Naganawa Y, Shibata T, Fujii Y and Takeyama H: Expression of CD44v6 is an independent prognostic factor for poor survival in patients with esophageal squamous cell carcinoma. Oncol Lett 2 : 429-434, 2011

19. Motohara T, Fujimoto K, Tayama S, Narantuya D, Sakaguchi I, Tashiro $\mathrm{H}$ and Katabuchi $\mathrm{H}$ : CD44 variant 6 as a predictive biomarker for distant metastasis in patients with epithelial ovarian cancer. Obstet Gynecol 127: 1003-1011, 2016.

20. Yang Q, Liu Y, Huang Y, Huang D, Li Y, Wu J and Duan M: Expression of COX-2, CD44v6 and CD147 and relationship with invasion and lymph node metastasis in hypopharyngeal squamous cell carcinoma. PLoS One 8: e71048, 2013.

21. Liu HG, Lv L and Shen H: Intratumoral heterogeneity of CD44v6 in rectal cancer. Clin Transl Oncol 19: 425-431, 2017.

22. Spiegelberg D, Kuku G, Selvaraju $R$ and Nestor $M$ : Characterization of CD44 variant expression in head and neck squamous cell carcinomas. Tumour Biol 35: 2053-2062, 2014.

23. Spiegelberg D and Nilvebrant J: CD44v6-targeted imaging of head and neck squamous cell carcinoma: Antibody-based approaches. Contrast Media Mol Imaging 2017: 2709547, 2017.

24. Haylock AK, Spiegelberg D, Mortensen AC, Selvaraju RK, Nilvebrant J,Eriksson O, Tolmachev V and Nestor MV: Evaluation of a novel type of imaging probe based on a recombinant bivalent mini-antibody construct for detection of CD44v6-expressing squamous cell carcinoma. Int J Oncol 48: 461-470, 2016.

25. Spiegelberg D, Mortensen AC, Selvaraju RK, Eriksson O, Stenerlöw B and Nestor M: Molecular imaging of EGFR and CD44v6 for prediction and response monitoring of HSP90 inhibition in an in vivo squamous cell carcinoma model. Eur J Nucl Med Mol Imaging 43: 974-982, 2016.

26. Börjesson PK, Postema EJ, Roos JC, Colnot DR, Marres HA, van Schie MH, Stehle G, de Bree R, Snow GB, Oyen WJ, et al: Phase I therapy study with (186)Re-labeled humanized monoclonal antibody BIWA 4 (bivatuzumab) in patients with head and neck squamous cell carcinoma. Clin Cancer Res 9: 3961S-3972S, 2003.

27. Jødal L: Beta emitters and radiation protection. Acta Oncol 48: 308-313, 2009

28. Mujammami M, Hier MP, Payne RJ, Rochon L and Tamilia M: Long-term outcomes of patients with papillary thyroid cancer undergoing remnant ablation with 30 milliCuries radioiodine. Thyroid 26: 951-958, 2016.

29. Makis W, McCann K and McEwan AJ: Orbital metastases of neuroendocrine tumors treated with ${ }^{177} \mathrm{Lu}$-DOTATATE PRRT or 131I-MIBG therapies. Clin Nucl Med 41: 137-141, 2016.

30. Bergsma H, Konijnenberg MW, van der Zwan WA, Kam BL, Teunissen JJ, Kooij PP, Mauff KA, Krenning EP and Kwekkeboom DJ: Nephrotoxicity after PRRT with (177)Lu-DOTAoctreotate. Eur J Nucl Med Mol Imaging 43: 1802-1811, 2016.

31. NuDat 2 [Internet]. Cited Mar 7, 2017. Available from: http://www. nndc.bnl.gov/nudat $2 /$.
32. Hindié E, Zanotti-Fregonara P, Quinto MA, Morgat C and Champion C: Dose deposits from ${ }^{90} \mathrm{Y},{ }^{177} \mathrm{Lu},{ }^{111} \mathrm{In}$, and ${ }^{161} \mathrm{~Tb}$ in micrometastases of various sizes: Implications for radiopharmaceutical therapy. J Nucl Med 57: 759-764, 2016.

33. Wang G, Wu Z, Wang Y, Li X, Zhang G and Hou J: Therapy to target renal cell carcinoma using 131I-labeled B7-H3 monoclonal antibody. Oncotarget 7: 24888-24898, 2016.

34. Long B, Yang M, Yang Z, Yi H and Li L: Assessment of radioiodine therapy efficacy for treatment of differentiated thyroid cancer patients with pulmonary metastasis undetected by chest computed tomography. Oncol Lett 11: 965-968, 2016.

35. Steidl S, Ratsch O, Brocks B, Dürr M and Thomassen-Wolf E: In vitro affinity maturation of human GM-CSF antibodies by targeted CDR-diversification. Mol Immunol 46: 135-144, 2008.

36. Ostendorp R, Frisch C and Urban M: Generation, engineering and production of human antibodies using hucal. In: Antibodies. Subramanian G (ed). Springer, US, pp13-52, 2004.

37. Cho MS, Yee H and Chan S: Establishment of a human somatic hybrid cell line for recombinant protein production. J Biomed Sci 9: 631-638, 2002.

38. Wolff $\mathbf{J}$ and Chaikoff IL: Plasma inorganic iodide as a homeostatic regulator of thyroid function. J Biol Chem 174: 555-564, 1948.

39. Eng PH, Cardona GR, Fang SL, Previti M, Alex S, Carrasco N, Chin WW and Braverman LE: Escape from the acute Wolff-Chaikoff effect is associated with a decrease in thyroid sodium/iodide symporter messenger ribonucleic acid and protein. Endocrinology 140: 3404-3410, 1999.

40. Tolmachev V, Malmberg J, Estrada S, Eriksson O and Orlova A: Development of a 124I-labeled version of the anti-PSMA monoclonal antibody capromab for immunoPET staging of prostate cancer: Aspects of labeling chemistry and biodistribution. Int $\mathrm{J}$ Oncol 44: 1998-2008, 2014

41. Sehlin D, Fang XT, Meier SR, Jansson M and Syvänen S: Pharmacokinetics, biodistribution and brain retention of a bispecific antibody-based PET radioligand for imaging of amyloid- $\beta$. Sci Rep 7: 17254, 2017.

42. Haylock A-K, Spiegelberg D, Nilvebrant J, Sandström K and Nestor M: In vivo characterization of the novel CD44v6-targeting Fab fragment AbD15179 for molecular imaging of squamous cell carcinoma: A dual-isotope study. EJNMMI Res 4: 11, 2014.

43. Steffen AC, Wikman M, Tolmachev V, Adams GP, Nilsson FY, Ståhl S and Carlsson J: In vitro characterization of a bivalent anti-HER-2 affibody with potential for radionuclide-based diagnostics. Cancer Biother Radiopharm 20: 239-248, 2005

44. Brown BA, Comeau RD, Jones PL, Liberatore FA, Neacy WP, Sands $\mathrm{H}$ and Gallagher BM: Pharmacokinetics of the monoclonal antibody B72.3 and its fragments labeled with either ${ }^{125} \mathrm{I}$ or ${ }^{111} \mathrm{In}$. Cancer Res 47: 1149-1154, 1987.

45. Ahl PL, Bhatia SK, Meers P, Roberts P, Stevens R, Dause R, Perkins WR and Janoff AS: Enhancement of the in vivo circulation lifetime of L-alpha-distearoylphosphatidylcholine liposomes: Importance of liposomal aggregation versus complement opsonization. Biochim Biophys Acta 1329: 370-382, 1997.

46. Holechek MJ: Glomerular filtration: An overview. Nephrol Nurs J 30: 285-290; quiz 291-292, 2003.

47. Blau M: Letter: Radiation dosimetry of 131-I-19-iodocholesterol: The pitfalls of using tissue concentration data. J Nucl Med 16: 247-249, 1975.

This work is licensed under a Creative Commons Attribution-NonCommercial-NoDerivatives 4.0 International (CC BY-NC-ND 4.0) License. 